\title{
CIVIC-MINDED GRADUATE: ADDITIONAL EVIDENCE
}

\author{
Robert G. Bringle and Elizabeth Wall
}

\section{Abstract}

The civic-minded graduate (CMG) construct provides a set of common civic learning objectives that can guide the design, implementation, and assessment of curricular and cocurricular civic engagement programs. This research examined components posited to be part of the CMG construct and found correlations between identity as a student and $C M G$, between civic identity and $C M G$, between $C M G$ and all of the motives for volunteering on the Volunteer Functions Inventory, and between CMG and measures of interest in charity, service programs, and advocacy types of service. Implications for practice and future research are proffered.

The sine qua non of service-learning as well as some cocurricular civic engagement programs (Bringle, Studer, Wilson, Clayton, \& Steinberg, 2011; Jacoby, 2015; Weinberg, 2005) is to develop democratically based civic attitudes, civic knowledge, civic skills, and civic intentions in students so that they can be engaged and effective citizens who contribute to the public good during their lives and careers (Hatcher, 2008). Because higher education is increasingly expected to support graduates who are committed to lifelong habits of civic engagement (Bringle, Games, \& Malloy, 1999; Colby, Ehrlich, Beaumont, \& Stephens, 2003; Percy, Zimpher, \& Brukardt, 2006; Saltmarsh \& Hartley, 2011), the availability of clear conceptual frameworks that detail the nature of students' civic outcomes is important to progress on designing programs and conducting research. There is no commonly accepted set of outcomes for civic education (Battistoni, 2013; Hatcher, Bringle, \& Hahn, 2017; Hemer $\&$ Reason, 2017). For example, Battistoni (2002) identified 12 different meanings of citizenship, civic education, and associated civic skills, each linked to a cluster of disciplines and professions: (a) liberalism, (b) communitarianism, (c) participatory democracy, (d) public work, (e) social capital, (f) civic professionalism, (g) social responsibility, (h) social justice, (i) connected knowing and the ethic of care, (j) public leadership, (k) public intellectual, and (l) engaged or public scholarship. The diversity of these meanings may be advantageous because it provides opportunities for educators to align specific outcomes with particular types of cultural or political orientations, educational and disciplinary content, and community activities. However, the heterogeneity of dimensions of civic outcomes can inhibit systematic scholarship, practice, and research on civically engaged pedagogies and programs (Hemer \& Reason, 2017). 
Because civic learning is a multifaceted category of learning with multiple perspectives and learning objectives (Battistoni, 2002, 2013; Hemer \& Reason, 2017), the civic-minded graduate (CMG) construct was developed to integrate various conceptualizations of civic learning outcomes across both curricular and cocurricular initiatives (Bringle, Brown, Hahn, \& Studer, 2019; Bringle \& Steinberg, 2010; Bringle et al., 2011; Steinberg, Hatcher, \& Bringle, 2011). A CMG is defined as:

a person who has completed a course of study (e.g., bachelor's degree), and has the capacity and desire to work with others to achieve the common good. "Civic-Mindedness" refers to a person's inclination or disposition to be knowledgeable of and involved in the community, and to have a commitment to act upon a sense of responsibility as a member of that community. (Bringle \& Steinberg, 2010, p. 429)

Civic-mindedness is viewed as distinct from orientations that emphasize one's self, family, or a corporate or profit motive. Because civic learning is an intentional aspect of service-learning and some cocurricular service programs, having a conceptual framework and measurement tools to capture civic learning can provide an important basis for evaluating student civic outcomes at multiple levels (e.g., person, course, program, institution). This can be helpful to practitioners who design civically oriented courses or programs and those who evaluate them.

The CMG construct is composed of 10 conceptual domains (Steinberg et al., 2011, p. 22): (a) knowledge of volunteer opportunities, (b) academic knowledge and technical skills, (c) knowledge of contemporary social issues, (d) communication and listening skills, (e) appreciation of and sensitivity to diversity, (f) skills to build consensus, (g) valuing community engagement, (h) self-efficacy, (i) social trustee of knowledge, and (j) intentions to be personally involved in community service. These attributes of CMG are viewed as being common across curricular and cocurricular programs that have civic learning as a focus (Bringle et al., 2011). Although they are not an exhaustive list of civic attributes, they are a sample of civic attributes that can index civic development. Previous work described the process of arriving at this list of attributes, suggested how they can be related to curricular and cocurricular programming, and described methods for measuring CMG (Bringle et al., 2011; Bringle, Brown, et al., 2019; Bringle \& Steinberg, 2010; Steinberg et al., 2011).

Concerning measurement, Steinberg et al. (2011) used three different methods for measuring CMG: (a) a CMG Scale, which is comprised of 30 self-report items; (b) a CMG Narrative Prompt, which produces a written narrative that is scored with a rubric; and (c) a CMG Interview Protocol, which is scored with a rubric. Generally, these three assessment strategies demonstrated convergence in measuring CMG (Steinberg et al., 2011). In addition, the CMG Scale was found to have a non-significant correlation with social desirability, a single factor structure, high internal consistency as measured by coefficient alpha, and a significant positive correlation with Morton's Integrity Scale (Bringle, Hatcher, \& McIntosh, 2006), which measures the degree to which civic values and civic behaviors are aligned and integrated with one's self.

The present research offers additional supporting evidence for the CMG construct and further understanding of the nature of CMG. Steinberg et al. (2011) hypothesized that a civically minded person would be located at the intersection of three dimensions (see Figure 1). 
1. Identity—representative of one's self-understanding, self-awareness, and self-concept

2. Educational experiences-representative of one's commitment to educational experiences, academic knowledge, and technical skills

3. Civic experiences - representative of one's involvement with and commitment to the community

Individuals can have varying degrees of overlap or integration between and among these three dimensions. Little or no integration is indicative of individuals for whom these are disconnected arenas and/or underdeveloped aspects of their lives. For example, minimal integration of the academic domain with the self is indicative of those persons who do not identify with and take seriously the role of their education in their future lives, and they are relatively unengaged students. Lack of integration for the self and the civic realm means that their civic attitudes, values, and behaviors are not salient or well integrated into their identity. Civic identity has been identified as a superordinate outcome that encompasses civic knowledge, civic skills, civic attitudes, civic behavioral intentions, and civic behaviors (Bringle, Clayton, \& Bringle, 2015; Hemer \& Reason, 2017). A higher degree of integration of all three dimensions describes students who are dedicated to engaging actively in their studies to increase their capacity to undertake future civic activities (e.g., through a career or profession, civic involvement, volunteering, political activity) in such a way that they can contribute, through collaborative activities with others, to society and the public good.

Identity is a complex construct in both the sociological and the psychological literature. Deaux and Burke (2010) provide an analysis of identity and the unique and common elements of both sociological and psychological perspectives. Identity can be construed as being a function of roles, group membership (formal or informal), self-categorization, and socially defined meanings (Reicher, Spears, \& Haslam, 2010). Furthermore, individuals have multiple identities, typically assumed to be coherently organized. Identity provides a basis for reducing uncertainty about one's self and one's place in the world (Hogg \& Abrams, 1993), for being known and understood by others (i.e., self-verification through social interactions, Swann \& Read, 1981), for providing purpose (Damon, 2001; Malin, Reilly, Quinn, \& Moran, 2014), and for confirming the person's worth and motivating collective action from others (Klein, Spears, \& Reicher, 2007).

The nature of identity is viewed as being embedded within a social context. Virtually all theories assume that identity is not fixed but rather socially constructed through actions and interactions with others, including action and interactions in the civic realm (Bringle et al., 2015; Damon, 2001; Mitchell, Battistoni, Keene, \& Reiff, 2013; Swann \& Read, 1981; Yates \& Youniss, 2006). Knefelkamp (2008) described civic identity as the integration of (a) engagement with others; (b) complex intellectual (i.e., cognitive) and ethical development; (c) holistic practice (including empathy for others); and (d) multiple experiences and opportunities for learning, experimentation, and active reflection. Building on these themes, CMG is viewed as a form of civic identity that integrates the self-concept with both the educational domain and the civic domain (Steinberg et al., 2011). This research sought evidence for the presumption that CMG would be related to the degree to which individuals also demonstrated (a) integration of the self with their identity as a student, and (b) integration of the self with their civic identity. 


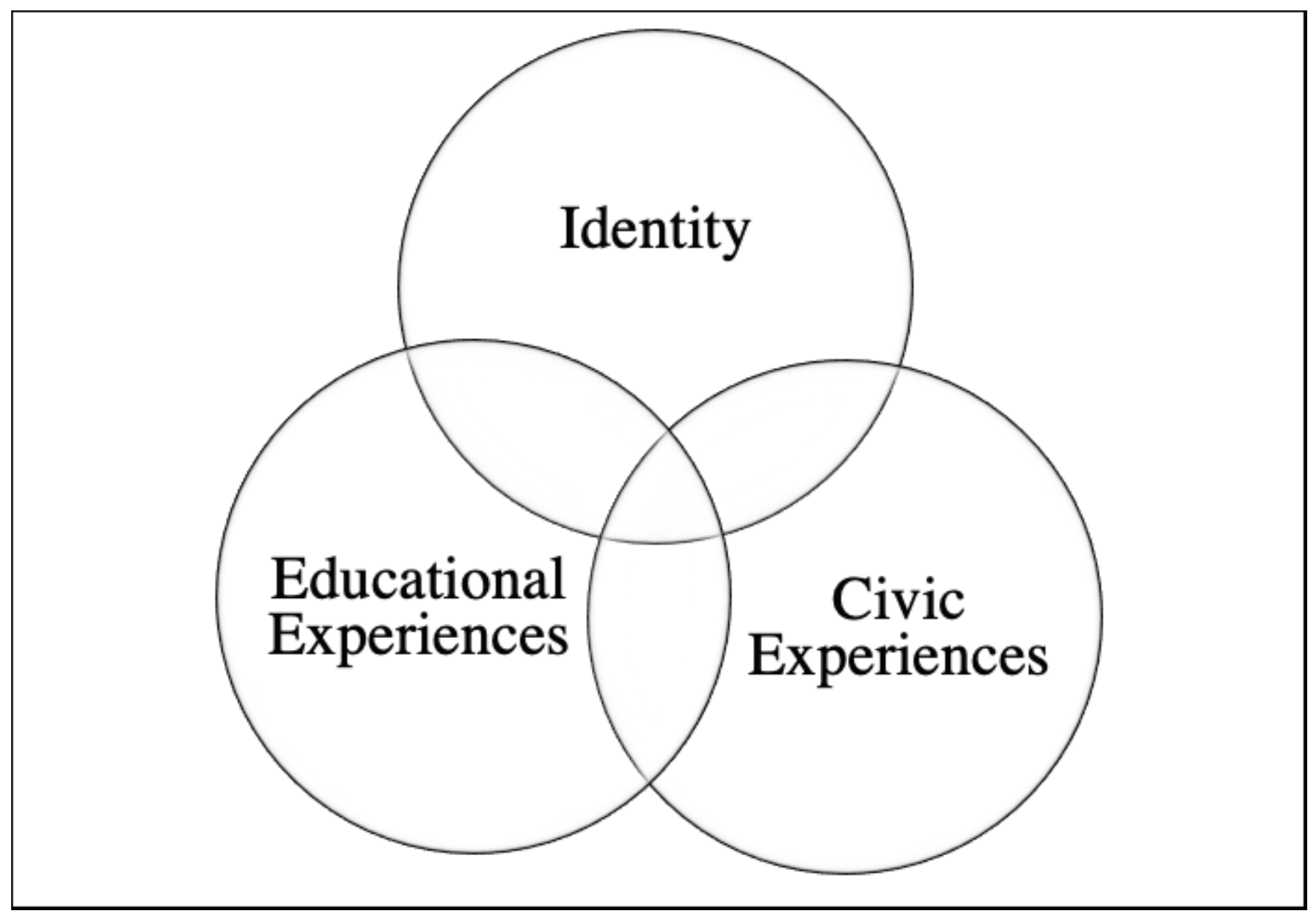

Figure 1.

Morton (1995) specified three different approaches to community service: charity (providing direct service to another person), project (implementing or participating in service programs through community service organizations), and social change (transformational models of systemic change). Morton proposed that each type of service is a separate paradigm; each has "its own logic, strengths, limitations and vision of a transformed world" (p. 19) and contains "a world view, a problem statement, and an agenda for change” (p. 24). This research explored the question of how CMG might be aligned with preferences with each of these three paradigms of service.

Persons with higher CMG are presumed to be motivated by altruistic concern for others. The Volunteer Functions Inventory (VFI) (Clary et al., 1998) provides a measure of the following six functions that are served through volunteer activities:

1. Values - the degree to which volunteering expresses altruistic and humanitarian concern for others

2. Understanding - the degree to which volunteering provides opportunities for new learning experiences and to use knowledge, skills, and abilities

3. Social-the degree to which volunteering allows the person to be with friends and receive the recognition of others

4. Career-the degree to which volunteering promotes clarity about vocational choices 
5. Protective-the degree to which volunteering allows the person to avoid guilt and better cope with personal problems

6. Enhancement - the degree to which volunteering promotes an individual's sense of personal growth and positive feelings

Consistent with the finding in Steinberg et al. (2011) that CMG correlated with Morton's Integrity Scale, which measures how the civic values and civic behaviors are aligned and integrated with the self, and with the presumption that CMG reflects civic values, CMG was expected to correlate with at least the Values subscale of the VFI.

\section{Methods}

\section{Sample}

A convenience sample of undergraduate students enrolled at Appalachian State University was either recruited during their enrollment in psychology courses or approached in the university student union to participate in the questionnaire study. Of the 132 study participants, 55 were male and 73 were female (four omitted indicating gender). Due to the nature of the study, the only requirement of respondents was they were age 18 or older. ${ }^{1}$

\section{Questionnaire}

The questionnaire was completed anonymously. The first section of the questionnaire collected demographic information from respondents as well as single items measuring the frequency of political involvement during the past four years (e.g., worked on political campaign, assisted with voter registration), community involvement through campus organizations or clubs, service through community organizations, and the number of servicelearning courses taken during college (None, 1-2, 3-4, 5 and above).

Civic-Minded Graduate Scale. The CMG Scale (Steinberg et al., 2011) is comprised of 30 items that sam-

ple four domains: knowledge, skills, dispositions, and behavioral intentions. For this survey, a 6-point response scale was used (Strongly Disagree to Strongly Agree). In addition, items were rewritten from the format used in Steinberg et al. (2011), and respondents were asked to respond to items for all of their college experiences, not just their experiences at a specific university, as was done in Steinberg et al. (2011). A sample statement follows: "My college education has given me the professional knowledge and skills that I need to help address community issues." Coefficient alpha measures internal consistency and reliability of a multi-item scale. The CMG Scale in this study had an acceptable coefficient alpha $=.95$, which is comparable to coefficient alpha $=.96$ in Steinberg et al. (2011).

1. Portions of the data from this sample were reported in Bringle, Hedgepath, and Wall (2018). 
Volunteer Functions Inventory. VFI (Clary et al., 1998) consists of 30 items, with a 7-point response format (Not at all important/accurate for you to Extremely important/accurate for you). VFI examines how volunteering can reflect different motivations of the volunteer due to the behavior serving different functions. The 30 items are divided into six subscales measuring the following functions of volunteering services, which had the following coefficient alphas in the current research: Values (alpha $=.88)$, Career (alpha $=.85)$, Protective (alpha $=.81)$, Understanding $($ alpha $=.82)$, Enhancement $($ alpha $=.86)$, and Social $($ alpha $=.91)$.

Civic Identity Scale. An original Civic Identity Scale was constructed for this research and consists of seven items using a 6-point response format. The scale's items sample two domains: three items focus on respondents' self-perception of their community involvement and civic identity using a 6-point response format (Not At All Like Me to Very Much Like Me), and four items focus on the degree to which respondents perceive that their friends and families associate involvement in the community with the respondent using a 6-point response format (Strongly Disagree to Strongly Agree; see Appendix A for items). The seven items had a coefficient alpha = .97 in the current research.

Student Identity Scale. An original Student Identity Scale consists of six items using a 6-point response format (Strongly Disagree to Strongly Agree). The items are statements that are indicative of the respondents' identity as a student from their point-of-view and from the perspective of those who know them (see Appendix A for items). This scale had a coefficient alpha $=.86$ in the current research.

Morton's Typology of Service Scale. Morton’s Typology of Service Scale was adapted from Morton (1995) by having four items that measured each of the three types of service: interest in providing direct service to individuals, being involved in programs or organizations that provide service, and advocating for social change (Bringle et al., 2006). The 12 items used a 6-point response format (Strongly Disagree to Strongly Agree). Due to an unacceptable coefficient alpha, only two items were used for the charity subscale. Reliabilities for the three subscales in the current research were as follows: Advocacy (coefficient alpha $=.80$ ), Direct Service (coefficient alpha $=.80)$, and Charity (coefficient alpha $=.64$ ).

\section{Results}

CMG was found to be correlated with the Civic Identity Scale, $r(127)=.64, p<.01$, and Student Identity Scale, $r(127)=.23, p<.05$. Bivariate correlations between the CMG and VFI subscales were Protective, $r(128)=.50$ $p<.01$; Values, $r(128)=.50, p<.01$; Career, $r(128)=.31, p<.01$; Social, $r(128)=.40, p<.01$; Understanding, $r(128)=.55, p<.01$; and Enhancement, $r(128)=.41, p<.01$. CMG was also significantly correlated with interest in providing direct service, $r(127)=.49, p<.01$; interest in service programs, $r(127)=.57, p<.01$; and interest in advocacy for social change, $r(127)=.60, p<.01$. Finally, CMG was correlated with frequency of volunteering at community organizations, $r(128)=.26, p<.01$; frequency of community engagement through campus organizations, $r(128)=.28, p<.01$; and the number of service-learning courses taken, $r(128)=.26, p<$ .01 ; but not political activities, $r(128)=.00, p>.05$.

A stepwise multiple regression analysis was used to evaluate the relative importance of the various bivariate 
correlates to CMG by sequentially considering which correlates were independent predictors of CMG. The regression analysis was conducted using CMG as the dependent variable and the following as independent variables: the Civic Identity Scale; the Student Identity Scale; age, gender, class in college; frequency of political, campus, and community engagement through volunteerism; number of service-learning courses taken; the six subscales of the VFI; and preferences for direct service, programs, and advocacy. Civic identity was the first significant predictor of CMG, $R=.64, F(1,125)=64.7, p<.01$, indicating that those who scored higher on the CMG Scale also reported greater levels of integration between civic experiences and the self. The second predictor of CMG was interest in advocacy, cumulative $R=.74, F(2,124)=58.53, p<.01$. The third predictor of CMG was the VFI Understanding subscale, cumulative $R=.76, F(3,123)=42.37, p<.01$.

To determine the relative importance of only the VFI subscales to CMG, a stepwise multiple regression was conducted with CMG as the dependent variable and the six subscales of the VFI as the predictors. The first predictor was Understanding, $R=.55, F(1,125)=55.7, p<.01$. The second predictor was Protective, cumulative $R=.60, F(2,124)=34.8, p<.01$. The third predictor was Values, cumulative $R=.62, F(3,123)=25.9, p<.01$.

Finally, the bivariate correlation between civic identity and student identity was $r(128)=.20, p<.05$, supporting the Venn diagram for CMG that they are rather separate domains, each of which is available to be integrated with self/identity.

\section{Discussion}

This research found correlations of CMG and the extent of student identity and between CMG and civic identity. Civic identity was more salient to CMG than student identity, presumably due to the greater salience of civic content in the CMG Scale items in contrast to content in the items related to personal status as a student. The finding that the CMG represents an integration of civic orientation with the self is consistent with Steinberg et al.'s (2011) finding that CMG correlated with Morton's concept of integrity. Integrity is viewed as the degree to which civic values and civic behaviors are aligned and integrated with the self. Morton (1995) contended that how a college student engages in any type of community service can have differing levels of integrity or depth. Higher levels of integrity are assumed to possess deeply held, internally coherent values; match between means and ends; describe a primary way of interpreting and relating to the world; offer a way of defining problems and solutions; and suggest a vision of what a transformed world might look like (Morton, 1995, p. 28). The current findings provide additional evidence that relates CMG to identity and point to the need for better understanding the origins of the developmental influences and educational processes that result in integrating the self with the educational and the civic domains.

Identity development continues into young adulthood. How does the civic identity develop, particularly in those students who enter college with weak civic identities (i.e., little overlap between civic and self)? Jones and Abes (2004) asked, "If service-learning does promote learning about the self, what is the nature of this learning and how is it sustained or integrated into one's evolving sense of self?” (p. 150). Their research identified three sources of influence on identity development: the relationship between self and others; emerging commitments 
to socially responsible work; and increased open-mindedness about new ideas, people, and experiences. They noted:

Nearly all participants spoke explicitly about how their service-learning experiences caused them to reflect on their values, beliefs, and attitudes in a way very few other activities had encouraged. Their experiences working at the community service sites enabled them to reflect on their upbringing in typically homogenous environments and what, as a result, they had come to take for granted in their own lives. (p. 154)

Thus, well-designed service-learning courses can provide excellent opportunities to influence the civic identity of students as well as their understanding for how their education can contribute to their future civic life.

The modest correlation between civic identity and student identity suggests that, in this sample and possibly more broadly in higher education, the student population does not have very strong alignment for these two areas. It also suggests that higher education through service-learning courses and cocurricular civic programs can play a role in strengthening the connection between these two components. That is, students can benefit from additional curricular and cocurricular opportunities to explore how their education relates to their current and future civic involvement. As Bringle et al. (2015) noted, strengthening the connection between civic identity and educational outcomes is most likely to be fostered through democratically engaged community-campus partnerships and critical reflection. Stokamer and Clayton (2017) presented the case for the centrality of inclusivity, criticality, and cocreation to civic learning. However, the role of any of these has yet to be explored from a developmental and longitudinal perspective (Hill, Pasquesi, Bowman, \& Brandenberger, 2017). Using a related measure of civic-mindedness, Richard, Keen, Hatcher, and Pease (2016) found that alumni of the Bonner's Scholars Program who were more civic-minded professionals after graduation reported a greater number of civic activities and more volunteering during college. They also identified previous dialogue across difference and reflection during college years as significant correlates for long-term civic development and involvement. This research suggests factors, along with other developmental and programmatic factors, that need to be explored in prospective longitudinal research.

CMG was found in the current research to be related to a broad range of motives for volunteering, with understanding, protective, and altruistic values being independently related to CMG scores. The bivariate correlations and the multiple regression analyses support the coexistence, rather than the dialectic, of altruistic and self-oriented motives for civic engagement. Clary et al. (1998) reported that volunteer satisfaction and persistence were greater when service activities matched the volunteer's motive and that a breadth of strong motives means that volunteers will more likely continue their civic activities even if a particular motive is not satisfied (vs. volunteers who are motived by a single motive that might not be satisfied). Thus, the strong bivariate correlations between the six motives and CMG indicate that civic-minded students will likely have higher persistence and resiliency during community service experiences because of the diversity of motives supporting their civic action. Because motives are dynamic, engaging students in community service for one reason (e.g., it is required, self-interest) can be transformed into other motives (e.g., caring about an individual or a social 
issue) (Snyder \& Omoto, 2008). Therefore, having students explore the breadth of their motives that are related to their community-based activities and those of other persons (e.g., peers, staff at nonprofit agencies, community volunteers at the site, nonprofit board members) through reflection activities, key readings, and discussions with role models can help students appreciate multiple ways in which civic engagement can be rewarding and fulfilling. Thus, course and program features (e.g., types of service activities, reflection activities, key readings) can be designed and selected to facilitate development of and an appreciation for different motives for engaging in community-based activities.

The correlations between CMG and each of Morton's (1995) three types of service imply that the most civicminded students are versatile because they expressed interest in different types of service activities, with no one type of service being dominant as a correlate. This is in spite of the findings by Bringle et al. (2006) that the three types of service were associated with somewhat different correlates and showed some discriminant validity. However, Bringle and colleagues also found that both charity and social change were significantly correlated with identity, and preferences for all three types of service were associated with both stronger identity and longer term commitment to service. Morton (1995) contended that students have a preference for only one paradigm. The results of the current research and those of Bringle et al. are inconsistent with Morton's assertion that the three types of service are separate paradigms and consistent with the conclusion that the most civically engaged students are comfortable with and have an interest in all three forms of civic involvement. Providing students with curricular and cocurricular opportunities to become familiar with and participate in each type of service seems worthwhile to developing and deepening civic-mindedness in students who can then incorporate different types of civic activities into their future civic lives.

\section{Implications for Practice}

Bringle et al. (2011) provided examples for how CMG can serve as a common framework for curricular and cocurricular service programs. In particular, they identified the following functions that CMG can provide:

(a) common understanding of and appreciation by the staff of the strengths of individual programs; (b) a delineation of knowledge, skills, and dispositions associated with civically oriented programs; (c) development of assessment procedures (scale, narrative analysis with rubrics, interviews) to evaluate CMG (Steinberg et al., [2011]); (d) the capacity to evaluate CSL programs and provide feedback to coordinators for program improvements; (e) a framework for enhancing civic learning in service-learning courses by more intentionally designing course activities in terms of CMG elements; ( $f$ ) a procedure for obtaining institutional assessment of students' civic outcomes across majors; (g) a way of communicating and discussing civic learning outcomes with various internal and external audiences; (h) a means for conducting research associated with civic growth that can evaluate components of developmental models as programmatic or mediating variables; (i) thinking and planning more intentionally and coherently about civic development; and (j) deepening partnerships with and contributions to the community. (Bringle et al., 2011, p. 22) 
They also noted that CMG can operate as a basis for evaluating civic growth at the level of the individual, course, program, department, school, and institution as well as across multiple campuses. For example, CMG can be the basis for an exit assessment of graduating students, both undergraduate and graduate, that provides a summary of civic outcomes for the institution as a whole and a profile for the civic outcomes of students in different departments or schools. In addition, institutional use of CMG could represent institutional civic outcomes for accreditation, funding priorities, strategic planning, awards, institutional research, and grant proposals.

Although there were correlations between number of service-learning courses taken and CMG in this research, in Steinberg et al. (2011) and in Bringle, Hahn, and Hatcher (2019), those findings fail to differentiate causality. The finding that Understanding was an important motive for those with higher CMG scores highlights how educationally meaningful community service within the context of a course is compatible with and may contribute to further integrating civic and academic domains with the self. However, these correlational results only suggest these possibilities. Too often, research on service-learning fails to account for self-selection of students into service-learning (i.e., those who are civically inclined are more likely to seek out service-learning courses; those who are not civically inclined are more likely to avoid or drop a course with a service-learning component) in contrast to research elucidating how the nature of those experiences contributes to influencing and deepening changes in civic learning outcomes and civic identity for all students (Steinberg, Bringle, \& McGuire, 2013).

How to produce civic growth in students, including those students for whom the civic domain is underdeveloped or has no or little integration into their identity, presents an important educational challenge. Research supports the conclusion that most entering college students have been socialized to uncritically follow external authority to define their beliefs, identities, and social relationships (Baxter Magolda, 2001; Baxter Magolda \& King, 2012; Jones \& Abes, 2004). Students may also not be predisposed to explore social injustice, advocacy for social change, and issues related to power and privilege (Jones, Gilbride-Brown, \& Gasiorski, 2005). For, as Boyle-Baise (2002) points out, "A charitable task probably will not generate insights for social change” (p. 33). High-quality service-learning courses can provide opportunities through the selection of community service activities, key readings, classroom discussions, democratic partnerships, and reflection activities to develop an appreciation for complex learning, allow students to explore multiple perspectives while also developing their personal authority, develop an appreciation for learning from others, provide opportunities for dialogue and collaboration with diverse others (Bowman, 2011; Pascarella et al., 2014), and critically evaluate expert and dominant points-of-view (Baxter Magolda \& Boes, 2017; Baxter Magolda \& King, 2004, 2012; Boes, 2006). Stokamer and Clayton (2017) identified inclusivity, criticality, and cocreation as being important elements of curricular design and implementation that will generate civic learning.

Malin et al. (2014) found that three factors were associated with defining purpose beyond self: life transitions (e.g., from high school to college), identity formation processes (e.g., for life purpose, for careers), and external supports and influences (e.g., family during adolescence, peers, structured opportunities for engaging in valued community roles). Thus, service-learning can contribute to students' developing ethical and moral reasoning, intercultural maturity, global citizenship, and leadership (Baxter Magolda \& King, 2004; Brandenberger, 2013 ; King \& Baxter Magolda, 2005) by providing structured opportunities to develop efficacy (i.e., make a difference 
through appropriately selected community activities); exploring civic roles and motives; understanding the relationship of their education to their current and future civic lives; and developing lifelong habits of social, cultural, and political involvement. Piliavin’s research (Piliavin \& Callero, 1991; Piliavin, Grube, \& Callero, 2002) demonstrated that when a role in the community (in her research, being a blood donor) and identity merge, donor involvement is more likely to persist. Although all of these developmental factors are not attributes that are directly posited for CMG, they are expected to align with CMG and contribute to its development. For example, King and Baxter Magolda (2005) found that participants who demonstrated more internal meaningmaking exhibited advanced levels of intercultural maturity, defined as "how people become increasingly capable of understanding and acting in ways that are interculturally aware and appropriate” (King \& Baxter Magolda, 2005, p. 573). This is consistent with the findings by Bringleet al. (2019) that positive attitudes toward diversity and lack of prejudicial thinking were associated with scoring higher on the CMG Scale.

We have intentionally referred to "service-learning courses and civic cocurricular programs" as we have discussed CMG. In contrast to practitioners and educators who have included cocurricular programs in the definition of service-learning (e.g., Jacoby, 2015), we have maintained a clear distinction between service-learning as being "course-based, credit bearing" (Bringle \& Hatcher, 2000, p. 274) and cocurricular civic programs. Nevertheless, we also recognize that service-learning courses and cocurricular civic programs (e.g., civic leadership programs; Bringle et al., 2011; Richard et al., 2016) can have structured programming aligned with clear civic learning objectives. When this occurs, CMG can provide a basis for academic affairs, student affairs, and other educational staff to collaborate on the design, implementation, evaluation, and research related to the variety of ways that civic outcomes can be achieved (e.g., Bringle et al., 2011; Weinberg, 2005).

\section{Future Research}

Given the influence of interactions with family and friends, diverse others, and mentored relationships on the development of identity, additional research can be conducted to explore the key experiences that produce the integration of self with both civic experiences and educational experiences. Steinberg et al. (2011) identified three developmental models that could inform identity development of CMG through service-learning courses. Deci and Ryan's (2000) self-determination theory provides a framework for examining the internalization of motivation. According to self-determination theory, people have three psychological needs that contribute to intrinsic motivation: relatedness, competence, and autonomy. Each of these could be integrated into the experiences of students in service-learning courses and explored through research on civic outcomes and the development of civic-mindedness. For example, Brown, Wymer, and Cooper (2016) found in a randomized control group study that autonomy-oriented helping (vs. dependency-oriented helping) resulted in more positive views of social equality. Second, the intergroup contact hypothesis identifies the conditions under which interactions between individuals who are different (e.g., race, socioeconomic class, age, education) can produce empathy, understanding, and more positive attitudes (Hewstone \& Brown, 1986). According to this theory, positive attitude change is most likely to occur when student interactions with individuals who are different from them 
have the following characteristics: (a) equal status of groups, (b) common goals, (c) contradiction of stereotypes, (d) long-term contact, and (e) norms against prejudice. The theory and the research that supports this theory (e.g., Hewstone \& Brown, 1986; Pettigrew \& Tropp, 2008) suggest that it is the nature of the interactions that can result in the favorable change in attitudes. The role of these factors in service-learning courses can be studied for civic outcomes, including CMG. Third, Baxter Magolda’s (2001; see also Baxter Magolda \& Boes, 2017) self-authorship model posits that growth of the mind that produces civic growth comes in a shift from uncritical reliance on external authority toward self-authorship and the internal capacity to craft one's beliefs, identities, and social relations. King and Baxter Magolda (2005) found that students who demonstrated more internal meaning-making exhibited advanced levels of intercultural maturity. These theories as well as other theories (Damon, 2001) provide a basis for conducting research to evaluate the key elements of civic development (Steinberg et al., 2011) and for conducting research on how particular characteristics of the design and implementation of service-learning experiences and cocurricular civic programs (Bringle et al., 2011; Bringle, Brown et al.,2019; Richard et al., 2016) can lead to integration between the self and the civic and educational domains.

The purpose of this research was to demonstrate that CMG represented integration with a person's civic identity and a person's identity as a student as well as exploring other components of the CMG framework. That the CMG correlated with measures of constructs that are explicitly or implicitly in the CMG self-report scale's item content (e.g., Values, civic engagement) was expected. However, measures of other components that are not explicitly contained in CMG self-report item content (e.g., types of service involvement, identity as a student, other motives of the VFI) provided evidence supporting CMG's construct validity and its implications for practice.

\section{Conclusion}

How individuals construe themselves and the meaning that they attach to attributes associated with selfdefinition have important consequences for social behavior, including the types of situations they are in, the types of individuals with whom they interact, how they evaluate aspects of their social world, and their expectations of and reactions to situations. This research has demonstrated that students who scored higher on the CMG Scale accepted inclusion in the categories of being civic and of being a student. Each of these components of identity makes other attributes salient and produces its own social reality. This supports the view that educationally informed civic identity can be a central component of social identity and presents the challenge of better understanding its nature and its development. This research adds to the evidence of the CMG construct by Steinberg et al. (2011) (e.g., content validity, convergent and discriminant validity, internal consistency, factor structure) and complements additional evidence gathered by Bringle, Hahn, et al. (-2019), which supports the position that CMG can be an important basis upon which civic outcomes can be assessed for individuals, curricular components (e.g., courses, certificates, minors, majors), cocurricular programs, institutions, and alumni. 


\section{References}

Battistoni, R. M. (2002). Civic engagement across the curriculum: A resource book for service-learning faculty in all disciplines. Boston, MA: Campus Compact.

Battistoni, R. M. (2013). Civic learning through service learning: Conceptual frameworks and research. In P. H. Clayton, R. G. Bringle, \& J. A. Hatcher (Eds.), Research on service learning: Conceptual frameworks and assessment, Vol. 2A: Students and faculty (pp. 111-132). Sterling, VA: Stylus.

Baxter Magolda, M. B. (2001). Making their own way: Narratives for transforming higher education to promote self-development. Sterling, VA: Stylus.

Baxter Magolda, M. B., \& Boes, L. M. (2017). Educational theory and student civic outcomes. In J. A. Hatcher, R. G. Bringle, \& T. W. Hahn (Eds.), Research on service learning and student civic outcomes: Conceptual frameworks and methods (pp. 115-133). Sterling, VA: Stylus.

Baxter Magolda, M. B., \& King, P. M. (2004). Learning partnerships: Theory and models of practice to educate for self-authorship. Sterling, VA: Stylus.

Baxter Magolda, M. B., \& King, P. M. (2012). Assessing meaning making and self-authorship: Theory, research, and application. ASHE Higher Education Report (Vol. 38, No. 3). San Francisco, CA: Jossey-Bass.

Boes, L. M. (2006). Learning from practice: A constructive-developmental study of undergraduate service learning pedagogy (Unpublished doctoral dissertation). Harvard University, Cambridge, MA.

Bowman, N. A. (2011). Promoting participation in a diverse democracy: A meta-analysis of college diversity experiences and civic engagement. Review of Educational Research, 81(1), 29-68.

Boyle-Baise, M. (2002). Multicultural service learning: Educating teachers in diverse communities. New York: Teachers College Press.

Brandenberger, J. W. (2013). Investigating personal development outcomes in service learning: Theory and research. In P. H. Clayton, R. G. Bringle, \& J. A. Hatcher (Eds.), Research on service learning: Conceptual frameworks and assessment, Vol. 2A: Students and faculty (pp. 133-156). Sterling, VA: Stylus.

Bringle, R. G., Brown, L. A., Hahn, T. W., \& Studer, M. (2019). Pedagogies and civic programs to develop competencies for democratic culture and civic learning outcomes. Bordón. Revista de Pedagogía, 71(3).

Bringle, R. G., Clayton, P. H., \& Bringle, K. E. (2015). From teaching democratic thinking to developing democratic civic identity. Partnerships: A Journal of Service Learning E' Civic Engagement, 6(1), 1-26.

Bringle, R. G., Games, R., \& Malloy, E. A. (1999). Colleges and universities as citizens: Issues and perspectives. In R. G. Bringle, R. Games, \& E. A. Malloy (Eds.), Colleges and universities as citizens (pp. 1-16). Needham Heights, MA: Allyn \& Bacon.

Bringle, R. G., Hahn, T. W., \& Hatcher, J. A. (2019). Civic-minded graduate: Additional evidence II. International Journal of Research on Service-Learning and Community Engagement, 7(1), Article 3.

Bringle, R. G., \& Hatcher, J. A. (2000). Institutionalization of service learning in higher education. The Journal of Higher Education, 71, 273-290. 
Bringle, R. G., Hatcher, J. A., \& McIntosh, R. (2006). Analyzing Morton’s typology of service paradigms and integrity. Michigan Journal of Community Service Learning, 13(1), 5-15.

Bringle, R. G., Hedgepath, A., \& Wall, E. (2018). “I am so angry I could ... help!” The nature of empathic anger. The International Journal of Research on Service-Learning and Community Engagement, 6(1), Article 3.

Bringle, R. G., \& Steinberg, K. (2010). Educating for informed community involvement. American Journal of Community Psychology, 46, 428-441.

Bringle, R. G., Studer, M., Wilson, J., Clayton, P. H., \& Steinberg, K. S. (2011). Designing programs with a purpose: To promote civic engagement for life. Journal of Academic Ethics, 9(2), 149-164.

Brown, M. A., Wymer, J. D., \& Cooper, C. S. (2016). The counter-normative effects of service-learning: Fostering attitudes toward social equality through contact and autonomy. Michigan Journal of Community Service Learning, 23(1), 37-44.

Clary, E. G., Snyder, M., Ridge, R. D., Copeland, J., Stukas, A. A., Haugen, J., \& Miene, P. (1998). Understanding and assessing the motivations of volunteers: A functional approach. Journal of Personality and Social Psychology, 74, 1516-1530.

Colby, A., Ehrlich, T., Beaumont, E., \& Stephens, J. (2003). Educating citizens: Preparing America's undergraduates for lives of moral and civic responsibility. San Francisco, CA: Jossey-Bass.

Damon, W. (2001). To not fade away: Restoring civil identity among the young. In D. Ravitch \& J. Viteritti (Eds.), Making good citizens: Education and civil society (pp. 122-141). New Haven, CT: Yale University Press.

Deaux, K., \& Burke, P. (2010). Bridging identities. Social Psychology Quarterly, 73, 315-320.

Deci, E. L., \& Ryan, R. M. (2000). The "what" and "why" of goal pursuits: Human needs and the selfdetermination of behavior. Psychological Inquiry, 11, 227-268.

Hatcher, J. A. (2008). The public role of professionals: Developing and evaluating the civic-minded professional scale (Doctoral dissertation). Retrieved from http://scholarworks.iupui.edu/handle/1805/1703

Hatcher, J. A., Bringle, R. G., \& Hahn, T. W. (Eds.). (2017). Research on student civic outcomes in service learning: Conceptual frameworks and methods. Sterling, VA: Stylus.

Hemer, K. M., \& Reason, R. D. (2017). Student civic outcomes in higher education. In J. A. Hatcher, R. G. Bringle, \& T. W. Hahn (Eds.), Research on student civic outcomes in service learning: Conceptual frameworks and methods (pp. 25-43). Sterling, VA: Stylus.

Hewstone, M., \& Brown, R. (1986). Contact is not enough: An intergroup perspective on the "contact hypothesis.” In M. Hewstone \& R. Brown (Eds.), Social psychology and society: Contact and conflict in intergroup encounters (pp. 1-44). New York: Basil Blackwell.

Hill, P. L., Pasquesi, K., Bowman, N. A., \& Brandenberger, J. W. (2017). Longitudinal research and student civic outcomes. In J. A. Hatcher, R. G. Bringle, \& T. W. Hahn (Eds.), Research on student civic outcomes in service learning: Conceptual frameworks and methods (pp. 283-302). Sterling, VA: Stylus.

Hogg, M. A., \& Abrams, D. (1993). Towards a single-process uncertainty reduction model of social motivation in groups. In M. A. Hogg \& D. Abrams (Eds.), Group motivation: Social psychological perspectives (pp. 173190). New York: Harvester Wheatsheaf. 
Jacoby, B. (2015). Service-learning essentials: Questions, answers, and lessons learned. San Francisco, CA: JosseyBass.

Jones, S. R., \& Abes, E. S. (2004). Enduring influences of service-learning on college students' identity development. Journal of College Student Development, 45, 149-166.

Jones, S. R., Gilbride-Brown, J., \& Gasiorski, A. (2005). Getting inside the “underside” of service-learning: Student resistance and possibilities. In D. W. Butin (Ed.), Service-learning in higher education: Critical issues and directions (pp. 3-24). New York: Palgrave Macmillan.

King, P. M., \& Baxter Magolda, M. B. (2005). A developmental model of intercultural maturity. Journal of College Student Development, 46, 571-592.

Klein, O., Spears, R., \& Reicher, S. (2007). Social identity performance: Extending the strategic side of SIDE. Personality and Social Psychology Review, 11, 28-45.

Knefelkamp, L. L. (2008). Civic identity: Locating self in community. Diversity E̊ Democracy, 11(2), 1-3.

Malin, H., Reilly, T. S., Quinn, B., \& Moran, S. (2014). Adolescent purpose development: Exploring empathy, discovering roles, shifting priorities, and creating pathways. Journal of Research on Adolescence, 24, 186-199.

Mitchell, T. D., Battistoni, R. M., Keene, A. S., \& Reiff, J. (2013). Programs that build civic identity: A study of alumni. Diversity $\Xi^{\circ}$ Democracy, 16(3), 22-23.

Morton, K. (1995). The irony of service: Charity, project and social change in service-learning. Michigan Journal of Community Service Learning, 2(1), 19-32.

Pascarella, E. T., Martin, G. L., Hanson, J. M., Trolian, T. L., Gillig, B., \& Blaich, C. (2014). Effects of diversity experiences on critical thinking skills over 4 years of college. Journal of College Student Development, 55(1), 86-92.

Percy, S. L., Zimpher, N. L., \& Brukardt, M. J. (Eds.) (2006). Creating a new kind of university. Institutionalizing community-university engagement. Bolton, MA: Anker.

Pettigrew, T. F., \& Tropp, L. R. (2008). How does intergroup contact reduce prejudice? Meta-analytic tests of three mediators. European Journal of Social Psychology, 38(6), 922-934.

Piliavin, J. A., \& Callero, P. L. (1991). Giving blood: The development of an altruistic identity. Baltimore, MD: Johns Hopkins University Press.

Piliavin, J. A., Grube, J. A., \& Callero, P. L. (2002). Role as a resource for action in public service. Journal of Social Issues, 58, 469-485.

Reicher, S. D., Spears, R., \& Haslam, S. A. (2010). The social identity approach in social psychology. In M. Wetherell \& C. T. Mohanty (Eds.), The Sage handbook of identities (pp. 45-62). London: Sage.

Richard, D., Keen, C., Hatcher, J. A., \& Pease, H. A. (2016). Pathways to adult civic engagement: Benefits of reflection and dialogue across difference in college service-learning programs. Michigan Journal of Community Service Learning, 23(1), 60-74.

Saltmarsh, J., \& Hartley, M. (Eds.). (2011). "To serve a larger purpose": Engagement for democracy and the transformation of higher education. Philadelphia: Temple University Press.

Snyder, M., \& Omoto, A. M. (2008). Who gets involved and why? The psychology of volunteerism. In E. S. C. 
Liu, M. J. Holosko, \& T. W. Lo (Eds.), Youth empowerment and volunteerism: Principles, policies and practices (pp. 3-26). Hong Kong: City University.

Steinberg, K. S., Bringle, R. G., \& McGuire, L. E. (2013). Attributes of high-quality research on service learning. In P. Clayton, R. Bringle, \& J. Hatcher (Eds.). Research on service learning: Conceptual frameworks and assessment, Vol. 2A: Students and faculty (pp. 27-53). Sterling, VA: Stylus.

Steinberg, K. S., Hatcher, J. A., \& Bringle, R. G. (2011). Civic-minded graduate: A north star. Michigan Journal of Community Service Learning, 18(1), 19-33.

Stokamer, S. T., \& Clayton, P. H. (2017). Student civic learning through service learning. In J. A. Hatcher, R. G. Bringle, \& T. W. Hahn (Eds.), Research on student civic outcomes in service learning: Conceptual frameworks and methods (pp. 45-65). Sterling, VA: Stylus.

Swann, W. B., Jr., \& Read, S. J. (1981). Acquiring self-knowledge: The search for feedback that fits. Journal of Personality and Social Psychology, 41, 1119-1128.

Weinberg, A. S. (2005). Residential education for democracy. Learning for Democracy, 1(2), 29-45.

Yates, M., \& Youniss, J. (Eds.) (2006). Roots of civic identity: International perspectives on community service and activism in youth. Cambridge, UK: Cambridge University Press.

\section{Notes}

\section{Appendix A}

Civic Identity Scale

1. Community involvement is an important part of who I am.

2. I would feel a loss if I were to stop involving myself in the community.

3. It is important to me that I continue to involve myself in the community.

4. Many people who I know would say I am involved in the community.

5. Many people would be surprised if I were to stop involving myself in the community.

6. I talk to the people I am close to about my community involvement.

7. The people I know think that community involvement is important to me.

Student Identity Scale

1. Many people think of me in terms of being a student.

2. It is important to me that I continue to further my education.

3. My friends and family think that being a student is important to me.

4. I would feel a loss if I had to withdraw from school. 
5. Being a student is an important part of who I am.

6. My friends and family would be surprised if I were to withdraw from school.

\section{Authors}

Robert G. Bringle (PhD, Social Psychology, University of Massachusetts, Amherst). Dr. Bringle is Chancellor's Professor Emeritus of Psychology and Philanthropic Studies and Senior Scholar in the IUPUI Center for Service and Learning. He served as Executive Director of CSL from 1994 to 2012. He was awarded the Thomas Ehrlich Faculty Award for Service Learning, the IUPUI Chancellor's Award for Excellence in Teaching, the Legacy of Service Award from Indiana Campus Compact, and the Distinguished Research Award from the International Association for Research on Service-Learning and Community Engagement.

Elizabeth Wall (BS, Psychology, Appalachian State University). Ms. Wall graduated from Appalachian State University in Psychology with a concentration in business. As an undergraduate student, Ms. Wall received two travel grants to present her research at regional and international conferences. 